\title{
Rationale and Design of a Prospective Study to Assess the Effect of Microcirculatory Antiplatelet and Vasodilation Therapy in Patients with Chronic Chagas Disease and Coronary Microvascular Disease
}

\author{
Leon Gustavo dos Reis Macedo, Daniel Conterno Lemos, Igor Matos Lago, Geraldo Luiz de Figueiredo, \\ Moysés de Oliveira Lima Filho, André Schmidt, Marcus Vinicius Simões, \\ Benedito Carlos Maciel, J. Antonio Marin-Neto
}

\begin{abstract}
Background: Studies on Trypanosoma cruzi infections and histopathologic studies in individuals with Chagas disease suggest that ischaemia plays a role in the pathogenesis of myocardial lesions in the chronic phase of the disease. These ischaemic disorders are caused by microcirculatory deregulation. Atypical angina is a common symptom in patients in the chronic phase of Chagas disease. In a large number of patients, despite the absence of significant angiographic coronary obstructions, the occurrence of perfusion abnormalities is documented by myocardial scintigraphy during stress, which is reversible after rest. Methods: This will be a single-centre, prospective, single cohort study with a therapeutic intervention followed by a late quantitative re-evaluation of myocardial perfusion defects initially detected in patients with Chagas disease and angiographically normal coronary arteries. Myocardial perfusion single-photon emission computed tomography (SPECT) will be performed before and 90 days after therapeutic intervention using Technetium ${ }^{99 \mathrm{~m}} \mathrm{Tc}$ ) sestamibi as a radiotracer and physical stress or vasodilation stimulation with dipyridamole. Therapeutic intervention will consist of acetylsalicylic acid (single daily dose of $100 \mathrm{mg}$ ) with verapamil ( $80 \mathrm{mg}$ b.i.d.; a total daily dose of $160 \mathrm{mg}$ ). The primary endpoint of the study is a $>50 \%$ reduction of the area of ischaemic myocardium calculated by the polar scintigraphic map. Conclusions: This will be the first study of a therapeutic approach to attenuate or reverse ischaemic
\end{abstract}

\section{RESUMO}

Base Racional e Plano de Estudo Prospectivo para Avaliar o Efeito de Terapêutica Antiplaquetária e Vasodilatadora Microcirculatória em Pacientes com Cardiopatia Chagásica Crônica e Distúrbios Microvasculares Coronários

Introdução: Há evidência, embasada por estudos em modelos experimentais de infecção pelo Trypanosoma cruzi, e também por investigações histopatológicas em humanos com a doença de Chagas, de que distúrbios de natureza isquêmica participem da patogênese de lesões miocárdicas na fase crônica da moléstia. Esses distúrbios isquêmicos derivam de desregulação microcirculatória. Dor precordial atípica é sintoma comum em pacientes na fase crônica da doença de Chagas. Em substancial proporção desses pacientes, apesar da inexistência de obstruções coronárias angiograficamente detectáveis, documenta-se com cintilografia miocárdica a ocorrência de distúrbios perfusionais durante o estresse, que são reversíveis após repouso. Métodos: Estudo unicêntrico, prospectivo, de coorte única, com intervenção terapêutica seguida de reavaliação quantitativa, após 90 dias, da área ventricular apresentando alterações perfusionais isquêmicas inicialmente detectadas em pacientes cardiopatas chagásicos com coronárias angiograficamente normais. A cintilografia miocárdica de perfusão será executada com o método SPECT, antes e após 90 dias da intervenção terapêutica, tendo o sestamibi-TC $C^{99 m}$ como radiotraçador e o esforço físico ou o estímulo vasodilatador com dipiridamol como estressores. A intervenção terapêutica consistirá de ácido acetilsalicílico (dose de 100 mg diária)

\footnotetext{
Laboratório de Hemodinâmica e Cardiologia Intervencionista, Divisão de Cardiologia, Hospital das Clínicas - Faculdade de Medicina de Ribeirão Preto, Universidade de São Paulo - Ribeirão Preto, SP, Brazil. Correspondence to: J. Antonio Marin Neto. Avenida Bandeirantes, 3.900 - Campus Universitário Monte Alegre - Ribeirão Preto, SP, Brazil - CEP 14048-900

E-mail: marin_neto@yahoo.com

Received on: 12/1/2011 • Accepted on: 2/6/2012
} 
myocardial perfusion abnormalities of microvascular origin in patients with chronic Chagas disease.

DESCRIPTORS: Chagas disease Myocardial ischaemia. Microvascular angina. Acetylsalicylic acid. Verapamil. associado a verapamil (dose diária de $160 \mathrm{mg}$, em duas tomadas de $80 \mathrm{mg}$ ). O desfecho primário do estudo será redução > 50\% da área ventricular de isquemia miocárdica reversível calculada pelo mapa polar da cintilografia miocárdica de perfusão. Conclusões: Este é o primeiro estudo de intervenção terapêutica para atenuar ou reverter alterações miocárdicas isquêmicas de origem microvascular em pacientes com cardiopatia chagásica crônica.

DESCRITORES: Doença de Chagas. Isquemia miocárdica. Angina microvascular. Ácido acetilsalicílico. Verapamil.
V arious studies have indicated that myocardial ischaemia, provoked by microcirculatory disorders, is an important pathogenetic mechanism in Chagas disease. Recently, two comprehensive publications have thoroughly reviewed the topic, and the most relevant issues are reported below. ${ }^{1,2}$

\section{HISTOPATHOLOGICAL STUDIES IN HUMANS}

Research performed during acute Chagas disease has demonstrated that microcirculatory perivascular inflammation is partly responsible for the myocardial degeneration observed. ${ }^{3}$ Other necropsy studies were conducted in patients who died during the chronic phase of the disease, and those studies have described intimal proliferation, luminal constriction and intramyocardial arterioles. ${ }^{4}$ Necropsy studies have indicated that microcirculatory abnormalities, including pronounced thickening of the basement membrane in capillaries, are caused by a diffusely distributed focal myocytolysis in specimens obtained through myocardial biopsy. ${ }^{5}$ The results of several other studies have supported the concept that abnormal patterns of vasodilation and vasoconstriction produce myocardial lesions in patients with Chagas disease. ${ }^{6-9}$ Focal cell necrosis and its immediate consequence, interstitial reparative fibrosis, which are detected in chagasic hearts, follow the same pattern observed in experimental models of myocardial lesion induced by ischaemia and reperfusion. Such considerations suggest that low-intensity and short transient microvascular dysfunction are essentially implicated in the pathogenesis of chronic Chagas cardiopathy. ${ }^{10,11}$ Studies on necrotic tissue correlating the presence of apical aneurysms with scores proportional to the myocardial mass and to the coronary irrigation condition concluded that ischaemia factors inhibited typical chagasic lesion formation. ${ }^{12}$ Other independent investigations have suggested that the typical ventricular aneurysms present in many patients with chronic Chagas cardiopathy may be due to the combination of microinfarctions, especially those induced in relatively less dense coronary vascular territories and where microcirculatory defects may occur through abnormal adrenergic hyperstimulation. ${ }^{13}$ This concept could represent a possible physiopathological link between the microcirculatory pathogenesis hypotheses and chronic Chagas cardiopathy. ${ }^{14}$

\section{STUDIES ON EXPERIMENTAL MODELS OF TRYPANOSOMA CRUZI INFECTION}

During the 1970s, histopathologic and histoenzymological studies in Wistar rats chronically infected with Trypanosoma cruzi or receiving repetitive injections of isoproterenol demonstrated similarities between the myocardial lesions detected in both experimental models. These studies also suggested that myofibrillar lesions with ischaemic aspects could be due to cardiotoxicity caused by excessive catecholamine stimulus. ${ }^{15}$

In experimental studies using the murine model of the Chagas disease, it was possible to detect, through histochemical techniques, myocardial ischaemia associated with coronary microvascular dysfunction resulting in occlusive platelet thrombus. ${ }^{16,17}$ In those experimental models, other structural microcirculatory abnormalities that affected intimal proliferation and focal vascular constriction were also described. ${ }^{18}$ Such alterations were attributed to endothelial lesions directly linked to infection by the parasite ${ }^{19}$ or indirectly produced by cellular immunological mechanisms. ${ }^{20}$

Microcirculatory alterations provoked by Trypanosoma cruzi infection may be dependent on excessive endothelin production, which inhibits the formation of CAMP, induces alveolar spasms and stimulates platelet adhesion to the endothelium. ${ }^{21}$ Another possibility is neuraminidase production through trypomastigotes of the Trypanosoma cruzi, which removes sialic acid from the endothelial surfaces, thus making them vulnerable to platelet attack and subsequent local thrombosis. ${ }^{22}$ Another physiopathological possibility is increasing levels of thromboxane-A2, which is detected in the murine model of the Chagas infection, reinforcing the tendency for platelet adhesion and aggregation and causing localised thromboses. ${ }^{23}$

It is well-known that an inflammatory infiltrate typically found in chagasic hearts causes the production of 
cytokines capable of inducing abnormal microvascular reactivity. A seminal study conducted in a murine model of Trypanosoma cruzi infection has demonstrated that these dysfunctions can be partially reversed through early administration of verapamil. This vasodilation agent has antiplatelet activity at the microvascular level, reduces mortality during the initial phase of infection, and attenuates the evolution of myocardial lesions during the chronic phase. ${ }^{24}$ Verapamil is capable of reversing microvascular dysfunctions (segmental spasms and capillary hypoflow) directly visualised when preparing cremasteric tissue of rats infected with Trypanosoma cruzi. ${ }^{25}$ Finally, other molecular mechanisms that interfere with microcirculatory functionality appear to exist in the Chagas cardiomyopathy. For example, calreticulin, a calcium-binding protein that is also present in the human heart, is capable of modulating the complementary system and inhibiting angiogenesis. ${ }^{26}$

\section{CLINICAL INVESTIGATIONS}

\section{Clinical aspects}

Initially, various clinical manifestations of chronic Chagas disease cardiopathy suggested the involvement of myocardial ischaemia in its pathogeneses. A large number of patients $(20 \%-50 \%)$ have chest pain with symptoms (pressure, burning) and locations (retrosternal) similar to those with angina; however, the chest pain usually does not have a consistent correlation with physical stress (it occurs frequently at rest), and in most cases, it is not alleviated with the use of nitrates. ${ }^{27}$ Simultaneously with these symptoms, many individuals with Chagas disease and patients with classic ischaemia through coronary obstruction exhibit alterations of the ST-segment compatible with myocardial ischaemia as well as Q waves indicating myocardial necrosis and areas of electric inactivity in the electrocardiography. ${ }^{27-29}$ Additionally, analogous to what was verified in patients with coronary disease, the presence of regional ventricular dyssynergia is detected in many patients with Chagas disease. ${ }^{30}$ Despite the clinical similarities between cardiopathies due to coronary obstruction and those due to infection with Trypanosoma cruzi, the coronary angiography almost invariably indicates angiographically normal coronaries in the latter, that is, coronaries without detectable obstructions in the epicardial arteries..$^{27,31,32}$

\section{Macrovascular coronary dysfunction}

Even if the angiographically observed coronary anatomy appears to be normal in patients with chronic Chagas, the functionality of coronary macrocirculation may be altered. Therefore, the vasodilation response to acetylcholine, which depends on endothelial integrity, may be depressed in contrast with the preservation of the response to adenosine, without endothelial action. ${ }^{33}$ Another study conducted at this laboratory, using quantitative coronary responses to hyperventilation tests and nitrate administration in chronic chagasic patients with atypical angina. ${ }^{34}$ Together, these results express the occurrence of abnormal regulation of epicardial coronary circulation related to endothelial and nonendothelial dysfunction in patients with chronic Chagas cardiopathy manifesting chest pain without coronary obstructive lesions observed through coronarography.

\section{Objective evidence of myocardial perfusion dysfunctions in humans with chronic Chagas heart disease}

In the 1970s, pioneering work by Kuschnir et al., 35,36 in Cordoba, Argentina using primitive nuclear techniques (measuring global myocardial flow with ${ }^{86}$ Rubidium) demonstrated that patients with chronic Chagas presented reduced myocardial perfusion at rest and also during stimulation due to physical strain, in comparison to normal controls, and similarly to those with chronic coronary disease.

Several independent studies conducted by various investigators using perfusion myocardial scintigraphy demonstrated the occurrence of remarkable perfusional disorders in the hearts of patients with chronic Chagas. ${ }^{32,34,37,38}$ In those studies, the coronary arteries were angiographically normal, and the results vehemently attest the possibility of microvascular alterations, according to experimental studies. ${ }^{32,34,37,38}$ One of those studies conducted in this laboratory using ${ }^{201}$ Thallium as a radiotracer indicated fixed, paradoxical and reversible defects in all of the 23 patients included. While the fixed defects (most likely indicating the presence of fibrosis) were mainly observed in ventricular areas, indicating akinesia and dyskinesia, the reversible defects (indicating ischaemia induced by physical stress) could be detected in eight $(35 \%)$ patients, usually in ventricular areas with normal segmental mobility or with relatively little impairment. ${ }^{38}$

Another investigation performed in the present laboratory using ${ }^{201}$ Thallium focused on the topographic correlation between the perfusion defects detected by the single-photon emission computed tomography (SPECT) method and the regional contraction abnormalities of the left ventricle in 37 patients with various stages of chronic Chagas cardiopathy. ${ }^{39}$ Corroborating the results of a previous study, perfusion abnormalities topographically related to the sites affected by the mobility alterations (apical region and inferior-posterior parts of the left ventricle) were detected in $78 \%$ of the patients. Notably, the reversible defects indicating myocardial ischaemia were observed in ventricular segments with preserved mobility in five of 12 patients with Chagas disease, without any other pathological manifestation of cardiopathy (undetermined form). Therefore, for the first time, perfusion defects compatible with myocardial 
ischaemia due to physical strain were detected early in chagasic patients (before manifesting cardiopathy), suggesting that microvascular dysfunctions precede and determine the occurrence of alterations related to contractions of the regional ventricle in later phases. This concept is particularly reinforced by verifying that reversible defects (ischaemic) were predominant precisely within myocardial areas where ventricular aneurysms usually developed.

The accumulation and retention of ${ }^{201}$ Thallium, which is the radiotracer used in the aforementioned studies, are not only affected by the regional flow but are also dependent on the metabolic state of the myocardial cell. Therefore, it is possible that the capture defects detected could be due to cell metabolism dysfunction, induced by the inflammatory infiltrate and not caused by abnormalities of the regional flow. Nevertheless, this hypothesis was rejected when a study was conducted in the present laboratory with 18 patients with chest pain severe enough to undergo coronarography. On this occasion, a flow tracer (microspheres marked with ${ }^{99 m}$ Technetium) was injected in the left ventricular cavity of the 18 patients who did not present coronary obstructions. ${ }^{34}$ In ten of these patients, perfusion defects were detected in 49 of 126 segments of the left ventricle $(39 \%)$. In $19(40 \%)$ of these segments with perfusion defects at rest, there was severe dyssynergia, most likely indicating extensive regional fibrosis. In contrast, the other $60 \%$ of the ventricular segments with perfusion defects occurred in the areas of normal or minimally reduced mobility. Again, this finding indicated that microvascular perfusion alterations should precede the development of contractile abnormalities, and could be occasionally implicated in its genesis.

The foregoing hypothesis was supported by another study conducted in the present study's laboratories, which demonstrated that the reversible ischaemic defects became irreversible in some of the patients when the perfusion study was repeated after a mean of 5.6 years. ${ }^{40}$ Among the 36 patients initially evaluated, $20(56 \%)$ presented reversible defects involving approximately $10.2 \pm 9.7 \%$ of the ventricular area tomographically outlined by perfusion myocardial scintigraphy. Another remarkable aspect was that the development of irreversibility clearly correlated with the loss of ventricular systolic function observed in 36 patients with Chagas cardiopathy.

\section{Physiopathological consequences and opportunities for therapeutic intervention}

Based on the evidence presented above, the physiopathological consequence of the microvascular dysfunction (which induces myocardial ischaemia) can be identified as the depression of the contractile ventricular function. It is possible to hypothesise that at least two mechanisms link these two physiopathological expressions of Chagas heart disease.

The first mechanism consists of a contractile state similar to that verified in ischaemic cardiopathies by coronary arterial disease with hibernating myocardial, when ventricular areas are submitted to chronic hypoperfusion. The only research initiative, conducted in the present laboratories, tested the hypothesis that the dyssynergic ventricular areas could be a consequence of myocardial hibernation. That study, which used the postextrasystolic potentiation technique during radiologic-contrast cineventriculography, demonstrated that it was possible to identify contractile reserve in many dyssynergic areas; therefore, it is still a viable reserve. ${ }^{40,41}$ However, the hypothesis was not supported; the viability hidden by dyssynergia and shown through postextrasystolic potentiation could predominate or only appear in regions showing reversible perfusion defects during myocardial scintigraphy. ${ }^{42}$

The second and perhaps most decisive mechanism would result in cellular death and consequent repairing fibrosis. In this context, there are relevant therapeutic implications potentially capable of attenuating, slowing, or even hindering the progression of myocardial dysfunction occasioned by ischaemic microcirculatory dysfunctions.

Although therapeutic studies aimed at avoiding myocardial ischaemia in chronic chagasic cardiopathy have not yet been conducted, some results of indirect research may be considered encouraging. Therefore, prolonged administration of dipyridamole ${ }^{43}$ or acute isosorbide dinitrate administration ${ }^{44}$ was associated with clear improvement of the left ventricular systolic function. Nevertheless, these studies did not demonstrate that the improvement of ventricular function was associated with myocardial ischaemia remission; it could simply result from more favourable haemodynamic conditions due to the effects of dipyridamole and dinitrate.

Therefore, there are still new perspectives for studies in which the symptoms and objective signs suggesting myocardial ischaemia caused by microvascular dysfunctions are attenuated or even reversed by agents acting at the microcirculatory level. This study proposes that patients with Chagas disease having the mentioned characteristics will have a medium-term follow-up and will be treated with the combination of a microvascular vasodilator (verapamil) and acetylsalicyclic acid acting as the inhibitor of platelet activation and aggregation.

\section{METHODS}

Patients with Chagas disease who will have underwent cardiac catheterism at the Haemodynamic and Interventional Cardiology Laboratories of the 
Cardiology Division of the Hospital das Clínicas in the Faculdade de Medicina of the Universidade de São Paulo in Ribeirão Preto will be selected. The patients must satisfy the following inclusion criteria: a) indication of exams due to chest pain, b) angiographically normal coronaries or coronaries without lesions $>30 \%$, c) preserved global left ventricular systolic function or only mildly impaired function (left ventricular ejection fraction $>40 \%$ ) and $d$ ) two positive serological tests for the diagnosis of Chagas disease using different methods (enzyme-linked immunosorbent assay [ELISA], haemaglutination or indirect immunofluorescence).

After this initial selection, the patients who do not present initial exclusion criteria will sign an informed consent. The initial exclusion criteria are a history of diabetes mellitus, severe systemic arterial hypertension (light or moderate controlled degrees are acceptable), heart rate $<60 \mathrm{bpm}$ or systolic arterial pressure $<90 \mathrm{mmHg}$, and use of or clinical need for negative chronotropic drugs (cardiac glycoside, adrenergic betablocker, or amiodarone).

After signing the informed consent, the patients will be submitted to laboratory evaluation: electrocardiography, 24-hour Holter monitor, renal and liver function tests, total cholesterol fraction tests, and fasting blood glucose test for eventual detection of additional exclusion criteria:

- $2^{\text {nd }}$ and $3^{\text {rd }}$ degree atrioventricular block;

- Sick sinus syndrome;

- Complex ventricular arrhythmia;

- Alteration of liver function (serum albumin $<3 \mathrm{~g} / \mathrm{dL}$ or total bilirubin $>1 \mathrm{mg} / \mathrm{dL}$ or prothrombin time $>25 \%$ of control);

- Alteration of renal function (creatinine > 1.4);

- Diabetes mellitus (fasting blood glucose test $>126 \mathrm{mg} / \mathrm{dL}$ ).

If there are no exclusion criteria, each patient will undergo a perfusion scintigraphy exam to detect reversible perfusion defects, which will be the last inclusion criteria. Those presenting the mentioned alterations will be treated with $80 \mathrm{mg}$ of verapamil twice a day $+100 \mathrm{mg}$ of acetylsalicylic acid for 90 days. After 90 days, the perfusion myocardial scintigraphy will be repeated.

The study outcomes will be verified 90 days after the beginning of treatment and will consist of: a primary outcome (reduction $\geq 50 \%$ of regional myocardial perfusion alterations) and secondary outcome (disappearance or gradual relief of chest pain).

Myocardial perfusion scintigraphy will be performed using the SPECT method with DST digital camera (Sopha Medical Vision - Twinsburg,, OH, USA) equipped with a dual detector, a rectangular vision field, a specific processor (NXT-P, Sopha Medical Vision), and a highresolution, low-energy collimator.

A stress test or vasodilator with dipyridamole will

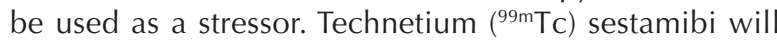
be used as a radiotracer to evaluate the regional myocardial blood flow, with a dose of $12 \mathrm{mCi}$ to $15 \mathrm{mCi}$ at rest and $25 \mathrm{mCi}$ to $30 \mathrm{mCi}$ during the stress peak.

\section{Sample calculus}

The sample calculus formula will be based on the following premises:

1) The scintigraphic methods and analyses will be the same as those used in the study that resulted in the article published in 2009, which analysed a population with Chagas disease with a profile similar to that predicted in this research; ${ }^{40}$

2) The left ventricular area of reversible perfusion defects measured in scintigraphic polar maps will be approximately $10.2 \%$, with $\sigma=9.7 \%$ in relation to the total ventricular area;

3) With a two-tailed test of 0.05 and $1 / \beta=0.8$, it is estimated that 63 patients will be necessary in order to detect at least a $50 \%$ reduction of the myocardial ischaemia area;

4) A $10 \%$ loss of patients was estimated between the first and second phases of the study; therefore, $63 /(1-0.1)=70$ patients;

5) Based on the aforementioned study, it is estimated that at least $56 \%$ of the patients initially considered will be part of the study after having verified the inclusion and exclusion criteria. To locate 70 patients with perfusion defects, it will be necessary to list 125 patients with the essential characteristics mentioned in this study.

To detect the difference between the two means, ${ }^{45}$ the sample formula was used: $N=2 . K . \sigma^{2} / \Delta^{2}$ in which $\mathrm{N}=$ number of patients, $\mathrm{K}=$ constant $=7,849$ for the values of $\alpha$ and $\beta$ defined above, $\sigma=9.7$ and $\Delta=4.85=50 \%$ of 10.2 .

\section{CONCLUSIONS}

This will be the first therapeutic intervention study aimed at attenuating or reversing microvascular myocardial ischemic alterations in patients with chronic Chagas disease.

\section{CONFLICTS OF INTEREST}

The authors declare no conflicts of interest. 


\section{REFERENCES}

1. Marin-Neto JA, Cunha Neto E, Maciel BC, Simões MV. Pathogenesis of chronic Chagas heart disease. Circulation. 2007;115(9):1109-23.

2. Rossi MA, Tanowitz HB, Malvestio LM, Celes MR, Campos EC, Blefari $\mathrm{V}$, et al. Coronary microvascular disease in chronic Chagas cardiomyopathy including an overview on history, pathology, and other proposed pathogenic mechanisms. PLoS Negl Trop Dis. 2010;4(8):e674.

3. Vianna G. Contribuição para o estudo da anatomia patológica da moléstia de Chagas. Mem Inst Oswaldo Cruz. 1911;3(2):276-94.

4. Torres CM. Miocitólise e fibrose do miocárdio na doença de Chagas. Mem Inst Oswaldo Cruz. 1960;58(1):161-82.

5. Ferrans VJ, Milei J, Tomiata Y, Storino RA. Basement membrane thickening in cardiac myocytes and capillaries in chronic Chagas' disease. Am J Cardiol. 1988;61(13):1137-40.

6. Laranja FS, Dias E, Nobrega G, Miranda A. Chagas' disease: a clinical, epidemiologic and pathologic study. Circulation. 1956;14(6):1035-59

7. Köberle F. Chagas' heart disease and Chagas syndromes: the pathology of American trypanosomiasis. Adv Parasitol. 1968;6:63-116.

8. Ferreira CS, Lopes ER, Chapadeiro E, Almeida HO, Souza WF, Silva Neto JJ. Coronariografia post-morten na cardite chagásica crônica: correlação anátomo-radiológica. Arq Bras Cardiol. 1980;34(2):81-6.

9. Higuchi ML, Brito T, Parzianello LC, Fukasawa S, Ramires JA. Severe arteriolar dilatation and ischemic lesions in chronic Chagas' cardiopathy: a 3D confocal laser microscopic study. J Am Coll Cardiol. 1998;31:382.

10. Morris SA, Tanowitz HB, Wittner M, Bilezikian JP. Pathophysiological insights into the cardiomyopathy of Chagas' disease. Circulation. 1990;82(6):1900-9.

11. Rossi MA. Microvascular changes as a cause of chronic cardiomyopathy in Chagas' disease. Am Heart J. 1990;120(1):233-6.

12. Oliveira JAM. Heart aneurysm in Chagas' disease. Rev Inst Med Trop São Paulo. 1998;40(5):301-7.

13. Higuchi ML, Fukasawa S, De Brito T, Parzianello LC, Bellotti G, Ramires JA. Different microcirculatory and interstitial matrix patterns in idiopathic dilated cardiomyopathy and Chagas' disease: a three dimensional confocal microscopy study. Heart. 1999;82(3):279-85.

14. Oliveira JSM, Santos JCM, Muccillo G, Ferreira AL. Increased capacity of the coronary arteries in chronic Chagas' heart disease: further support for the neurogenic pathogenesis concept. Am Heart J. 1985;109(2):304-8.

15. Oliveira JAM. Observações sobre a histoquímica de algumas enzimas do miocárdio na fase crônica da infecção experimental pelo Trypanosoma cruzi, Chagas, 1909, em ratos Wistar. Rev Goiana Med. 1976;22(1):1-65.

16. Rossi MA, Gonçalves S, Ribeiro-dos-Santos R. Experimental Trypanosoma cruzi cardiomyopathy in BALB/c mice: the potential role of intravascular platelet aggregation in its genesis. Am J Pathol. 1984;114(2):209-16.

17. Rossi MA, Carobrez SG. Experimental Trypanosoma cruzi cardiomyopathy in BALB/C mice: histochemical evidence of hypoxic changes in the myocardium. Br J Exp Pathol. 1985;66(2):155-60.

18. Factor SM, Cho S, Wittner M, Tanowitz HB. Abnormalities of the coronary microcirculation in acute murine Chagas' disease. Am J Trop Med Hyg. 1985;34(2):246-53.

19. Rossi MA. Aortic endothelial cell changes in the acute septicemic phase of experimental Trypanosoma cruzi infection in rats: scanning and transmission electron microscopy study. Am J Trop Med Hyg. 1997;57(3):321-7.
20. Andrade ZA, Andrade SG, Correa R, Sadigursky M, Ferrans VJ. Myocardial changes in acute Trypanosoma cruzi infection: ultrastructural evidence of immune damage and the role of microangiopathy. Am J Path. 1994;144(6):1403-11.

21. Morris SA, Tanowitz HB, Makman M. Trypanosoma cruzi: alteration of CAMP metabolism following infection of human endothelial cells. Exp Parasit. 1992;74(1):69-76.

22. Libby $\mathrm{P}$, Alroy J, Pereira MEA. A neuraminidase from Trypanosoma cruzi removes sialic acid from the surface of mammalian myocardial and endothelial cells. J Clin Invest. 1986;77(1):127-35

23. Tanowitz HB, Burns ER, Sinha KA, Kahn NN, Morris SA, Factor SM, et al. Enhanced platelet adherence and aggregation in Chagas' heart disease: a potential pathogenic mechanism for cardiomyopathy. Am J Trop Med Hyg. 1990;43(3):274-81.

24. Morris SA, Weiss LM, Factor SM, Bilezikian JP, Tanowitz H, Wittner M. Verapamil ameliorates clinical, pathological and biochemical manifestations of the experimental chagasic cardiomyopathy in mice. J Am Coll Cardiol. 1989;14(3):782-9.

25. Tanowitz HB, Kaul DK, Chen B, Morris SA, Factor SM, Weiss LM, et al. Compromised microcirculation in acute murine Trypanosoma cruzi infection. J Parasitol. 1996;82(1):124-30.

26. Ferreira V, Molina MC, Schwaeble W, Lemus D, Ferreira A Does Trypanosoma cruzi calreticulin modulate the complement system and angiogenesis?. Trends Parasitol. 2005;21(4):169-74.

27. Marin-Neto JA, Rasssi Jr A, Simões MV, Maciel BC, Schmidt A Chagas' heart disease. In: Yusuf S, Cairns JA, Camm AJ, Fallen EL, Gersh BJ, editors. Evidence-based cardiology. 3. ed. New York: Wiley Blackwell; 2010. p. 823-41.

28. Feit A, El-Sherif N, Korostoff S. Chagas' disease masquerading as coronary artery disease. Arch Intern Med. 1983;143(1):144-5

29. Simões MV, Mello Ayres E, Attab-Santos JL, Schmidt A, Pintya AO, Maciel BC, et al. Detection of myocardial ischemia in Chagas> heart disease patients with angina-like symptoms by the effort test and holter monitoring. Arq Bras Cardiol. 1993;60(5):315-9.

30. Hammermeister KE, Caeiro T, Crespo E, Palmero H, Gibson DG Left ventricular wall motion in patients with Chagas' disease. Br Heart J. 1984;51(1):70-6.

31. Arreaza N, Puigbó JJ, Acquatella H, Casal H, Giordano $\mathrm{H}_{\text {, }}$ Valecillos R, et al. Radionuclide evaluation of left ventricular function in chronic Chagas' cardiomyopathy. J Nucl Med. 1983;24(7):563-7.

32. Hagar JM, Rahintoola SH. Chagas' heart disease in the United States. N Engl J Med. 1991;325(11):763-8.

33. Torres FW, Acquatella H, Condado JA, Dinsmore R, Palácios IF. Coronary vascular reactivity is abnormal in patients with Chagas' disease. Am Heart J. 1995;129(5):995-1001.

34. Marin-Neto JA, Simões MV, Ayres-Neto EM, Santos JLA, Gallo Junior L, Amorim DS, et al. Studies of the coronary circulation in Chagas' heart disease. São Paulo Med J. 1995; 113(2):826-34.

35. Kuschnir E, Kustich F, Epelman M, Santamarina N, Podio RB. Valoration de fluxo miocardico con $\mathrm{Rb} 86$, en pacientes con cardiopatia chagasica, con insuficiencia coronaria y en controles normales. Parte 1: Estudios basales. Arq Bras Cardiol. 1974;27(1):187-96.

36. Kuschnir E, Kustich F, Epelman M, Santamarina N, Podio RB Valoration de fluxo miocardico con $\mathrm{Rb} 86$, en pacientes con cardiopatia chagasica, con insuficiencia coronaria y en controles normales. Parte 2: Respuesta al ejercicio y a la cardiotonificación aguda. Arq Bras Cardiol. 1974;27:721-32.

37. Castro R, Kuschnir E, Sgammini H. Evaluacion de la performance cardíaca y perfusion miocárdica com radiotrazadores em la cardiopatia chagásica crônica. Fed Arg Cardiol. 1988;17(2):226-31. 
38. Marin-Neto JA, Marzullo P, Marcassa C, Gallo Junior L, Maciel BC, Bellina CR, et al. Myocardial perfusion abnormalities in chronic Chagas> disease as detected by thallium-201 scintigraphy. Am J Cardiol. 1992;69(8):780-4.

39. Simões MV, Pintya AO, Marin GB, Sarabanda AV, Antloga CM, Pazin-Filho A, et al. Relation of regional sympathetic denervation and myocardial perfusion disturbances to wall motion impairment in Chagas cardiomyopathy. Am J Cardiol. 2000;86(9):975-81.

40. Hiss FC, Lascala TF, Maciel BC, Marin-Neto JA, Simões MV. Changes in myocardial perfusion correlate with deterioration of left ventricular systolic function in chronic Chagas cardiomyopathy. J Am Coll Cardiol Img JACC Cardiovasc Imaging. 2009;2(2):164-72.

41. Brandão JMM, Miziara A, Figueiredo GL, Lima Filho MO, Ayres-Neto EM, Marin-Neto JA. Potenciação pós-extrassistólica na cardiopatia chagásica crônica. Estudo com ventriculografia de contraste radiológico. Arq Bras Cardiol. 2005;84(5):376-80.
42. Miziara A, Marin-Neto JA, Marchini JFM, Figueiredo GL, Pintya AO, Simões MV, et al. Discinergia ventricular esquerda reversível identificada por potenciação pós-extrassistólica em miocardiopatia chagásica crônica não é causada por hibernação miocárdica. Rev Bras Cardiol Invasiva. 2009; 17(3):358-68.

43. Kuschnir E, Sgammini H, Castro R, Evequoz C, Ledesma R. Miocardiopatia chagásica crônica: effectos del dipiridamol sobre la dinâmica ventricular. Arq Bras Cardiol. 1983;41(5):373-8.

44. Marin-Neto JA, Souza ACS, Maciel BC, Gallo Juniorr L, lazigi N. Avaliação angiocardiográfica nuclear do efeito do dinitrato de isosorbitol em pacientes chagásicos. Arq Bras Cardiol. 1988;51(5):367-71.

45. Wassertheil-Smoller S. Biostatistics and epidemiology: a primer for health and biomedical professionals. 3. ed. New York: Springer Verlag; 2004 